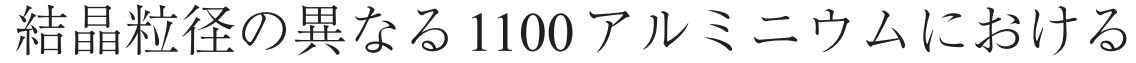 In-situ X線回折法を用いた引張変形中の転位密度測定
}

\author{
足立 大樹* . 宮嶋 陽司 $* *$. 佐藤 眞直 $* * *$. 辻 伸泰 $* * * *$
}

Journal of The Japan Institute of Light Metals, Vol. 64, No. 10 (2014), 463-469

(C) 2014 The Japan Institute of Light Metals

\section{Evaluation of dislocation density for 1100 aluminum with different grain size during tensile deformation by using In-situ X-ray diffraction technique}

\author{
Hiroki ADACHI*, Yoji MIYAJIMA**, Masugu SATO*** and Nobuhiro TSUJI****
}

The ultra-fine grained (UFG) aluminum with the grain size of $260 \mathrm{~nm}$ was fabricated by annealing for the severely plastic deformed A1100 alloy. This UFG aluminum showed the $0.2 \%$ proof stress $\left(\sigma_{0.2}\right)$ of four times the stress that the conventional Hall-Petch relation showed. In this study, for the UFG aluminum, the fine-grained (FG) aluminum with the grain size of $960 \mathrm{~nm}$ and the coarse-grained (CG) aluminum with the grain size of $4.47 \mu \mathrm{m}$, dislocation density change during the tensile deformation was investigated by the In-situ XRD measurement using SPring- 8 . The dislocation density changed in four stages with increase in strain. The first stage was the elastic deformation region and the dislocation density hardly changed. Only in the CG aluminum, this stage was hardly observed and the stress in which the dislocation began to multiple $\left(\sigma_{\mathrm{I}}\right)$ was almost $0 \mathrm{MPa}$. In the second stage, the dislocation density rapidly increased to $\rho_{\mathrm{II}}$ in which plastic deformation became possible at constant strain rate. In the third stage, the change became moderately. In the fourth stage, the dislocation density rapidly decreased by the fracture of test pieces. Additionally, the $\sigma_{0.2}-\sigma_{\mathrm{I}}$ were followed the conventional Hall-Petch relation regardless of grain size.

(Received April 29, 2014 Accepted June 23, 2014)

Keywords: ultra-fine grained aluminum, in-situ measurement, dislocation density, Hall-Petch relation

\section{1. 緒言}

近年, 繰返し重ね接合圧延 (ARB) 法 ${ }^{1) \sim 3}$, 圧縮ねじり 加工 (HPT) 法 $^{4)}$, Equal Channel Angular Pressing (ECAP) 法 ${ }^{5)}$ などの巨大ひずみ加工法が開発されたことにより，アルミ ニウムにおいても平均結晶粒サイズが数 $100 \mathrm{~nm}$ の超微細粒 材の作製が容易となっている。従来粒径材においても，結 晶粒径を微細化すると, Hall-Petchの関係に従って平均粒径 の $-1 / 2$ 乗に比例して強度が増加することが経験的に知られ ている ${ }^{6), 7)}$ 。紙川らによると，99.99\% 純度アルミニウム合 金において，結晶粒径が $405 \mu \mathrm{m}$ から $20 \mu \mathrm{m}$ までは $0.2 \%$ 耐力 $\sigma_{0.2}(\mathrm{MPa})$ は $\sigma_{0.2}=9.7+41 d^{-1 / 2}$ に従って変化することが報告 されている ${ }^{8)}$ 。ここでd $(\mu \mathrm{m})$ は平均結晶粒径である。しか しながら，巨大ひずみ加工法を用いて結晶粒径をさらに微細 にすると，この式で計算される応力よりもかなり大きくなる こともまた報告されている ${ }^{8)}$ 。例えば前述の式に $d=1 \mu \mathrm{m}$ を 代入すると $\sigma_{0.2}=50.7 \mathrm{MPa}$ になるが, 実際の $0.2 \%$ 耐力はその 倍の $100 \mathrm{MPa}$ 程度を示す。この現象はIF鋼でも観察されてお
$り^{9)}$ ，微細結晶粒材では，従来の Hall-Petch 曲線よりも高い 降伏応力を示すことがあると考えられる。また, ARB加工 により作製した粒径 $200 \mathrm{~nm}$ の超微細粒アルミニウムに低温 焼なましを施すことによりARBまま材よりも延性が大幅に 低下し, 強度が増加する。さらに, 焼なまし材に低圧下率 の圧延を施すと，ARBまま材と同程度まで延性が増加する ことが報告されている ${ }^{10), 11) 。 こ の ~ “ H a r d e n i n g ~ b y ~ a n n e a l i n g . ~}$ Softening by deformation” と呼ばれる現象は従来粒径材が示 す性質とは正反対である。このように超微細粒アルミニウム では従来材では見られない様々な特異な力学現象を示すこと から，変形を担う転位の挙動が従来粒径材とは異なっている のであろうと予測されるが，詳細は未だ明らかになっていな い。よって, 本研究では引張変形中における転位の挙動のう ち, 転位増殖挙動に注目し, 結晶粒径によりどのように変化 するかを明らかにすることを試みた。

転位密度を求める方法として, 電気抵抗による方法 ${ }^{12)}$, 透過電子顕微鏡（TEM）を用いる方法 ${ }^{13)}$ とX 線回折 (XRD) による方法が挙げられる。しかしながら，電気抵抗に対する

*兵庫県立大学大学院工学研究科（７６71-2280 兵庫県姫路市書写 2167)。University of Hyogo, Graduate School of Engineering (2167 Shosha, Himeji-shi, Hyogo 671-2280). E-mail: adachi@eng.u-hyogo.ac.jp

**東京工業大学大学院総合理工学研究科材料物理科学専攻 (東京都)。Tokyo Institute of Technology, Interdisciplinary Granduate School of Science and Engineering (Meguro-ku, Tokyo).

***高輝度光科学研究センター (JASRI) (兵庫県)。Japan Synchrotron Radiation Research Institute (JASRI) (Sayo-gun, Hyogo).

****京都大学大学院工学研究科材料工学専攻 (京都市)。Kyoto University, Graduate School of Engineering, Department of Materials Science and Engineering (Kyoto-shi, Kyoto) 
Table 1 Chemical composition of A1100 alloy in mass\%.

\begin{tabular}{c|c|c|c|c|c}
\hline \hline $\mathrm{Si}$ & $\mathrm{Fe}$ & $\mathrm{Cu}$ & $\mathrm{Mn}$ & $\mathrm{Zn}$ & $\mathrm{Al}$ \\
\hline 0.12 & 0.53 & 0.13 & 0.02 & 0.01 & 99.19 \\
\hline
\end{tabular}

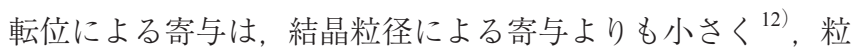
界密度が高い微細粒材では転位密度を正確に求めることが難 しいと予想される。また，TEM観察による方法では，TEM 観察用薄膜に加工した際に，表面近傍の転位密度が低下寸る こと ${ }^{14)}$ ，また，局所的な領域に打ける転位密度しか測定で きないことに加え, 表面効果により転位源の活動や転位の挙 動がバルク体のそれとは変化してしまう可能性があることな どが考えられる。したがって, 本研究では散乱体積内の平均 情報が得られるXRD測定による方法を採用した。XRD測定 結果から転位密度を算出する方法はWilliamsonらにより提案

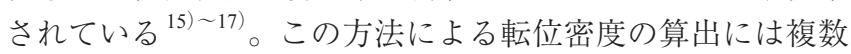
の回折ピークの半值幅を正確に測定することが必要であり, 広い回折角度範囲に扔いて $\mathrm{S} / \mathrm{N}$ 比のよい回折プロファイルを 得るための測定時間が必要である。そのために引張試験中に クロスヘッド移動を途中で停止させ，ストローク保持中に回 折プロファイルを測定する方法が用いられている ${ }^{18), 19) 。 し ~}$ かしながら，こういった間歇的測定では，ストローク保持中 に応力緩和が生じるため, 連続引張変形中に扮ける転位密度 よりも減少し, 過小評価する可能性がある。例えばTomota

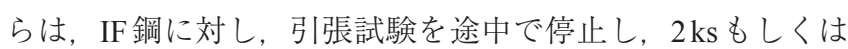
$4 \mathrm{ks}$ ストローク保持を行いながら中性子回折実験を行ってお り，その間に約 $25 \mathrm{MPa}$ 程度の応力低下が生じている ${ }^{18)}$ 。

よって, 引張変形を進めながら転位密度をIn-situ測定する ためには, 広い回折角度範囲にわたる回折プロファイル測 定を非常に短い時間で行うことができる測定系を構築する 必要がある。本研究では高輝度X線を用いることができる SPring-8放射光施設にて実験を行った。

\section{2. 実験方法}

厚さ $1 \mathrm{~mm}$ の A 1100 を $673 \mathrm{~K}, 7.2 \mathrm{ks}$ 均質化処理した後, 室温 まで泠却した。A1100の化学組成を Table 1 に示す。この試 料に ARB加工を室温にて8サイクル行い, 板厚 $0.5 \mathrm{~mm}$ の試 料を得た ${ }^{1)}$ 。ARB加工に打ける1サイクルは $50 \%$ 圧延である

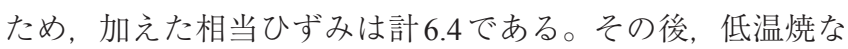
ましを行うことにより結晶粒径を調節した。（1） $373 \mathrm{~K}, 1.8 \mathrm{ks}$ 焼なましした材料，（2） $448 \mathrm{~K}, 21.6 \mathrm{ks}$ 予備焼なまし後に $498 \mathrm{~K}, 1.8 \mathrm{ks}$ 焼なましした材料，（3） $448 \mathrm{~K}, 21.6 \mathrm{ks}$ 予備焼なま し後に $578 \mathrm{~K}, 1.8 \mathrm{ks}$ 焼なましした材料の 3 種類である。一部 の試料で二段階焼なましを行っているのは, 低温での予備焼 なましを施すことにより焼なまし時の異常粒成長を抑制する ためである ${ }^{8)}$ 。これらの板材から RD方向が引張方向になる ように引張試験片を採取した。引張試験片の形状を Fig. 1 に 示す。

$\mathrm{SiC}$ 研磨紙による機械研磨およびコロイダルシリカによる 化学機械研磨により試料の ND-TD断面を鏡面研磨した後, 加速電圧 $15 \mathrm{kV}$ でEBSD測定を行った。EBSD測定は日本電 子製走査型電子顕微鏡 JSM- $6500 \mathrm{~F}$ に搭載した TSL 製 OIM を 用いて行った。その後, ND方向の大角粒界の間隔を測定し,

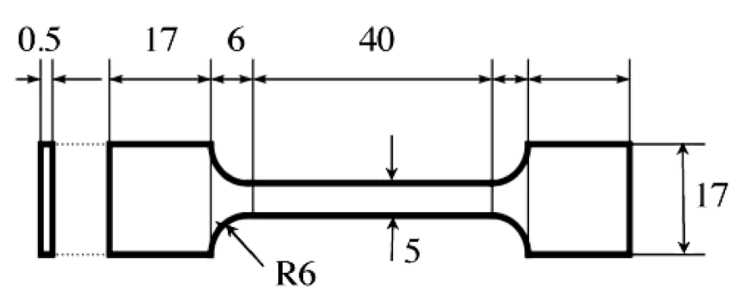

Fig. 1 The shape of tensile test pieces.

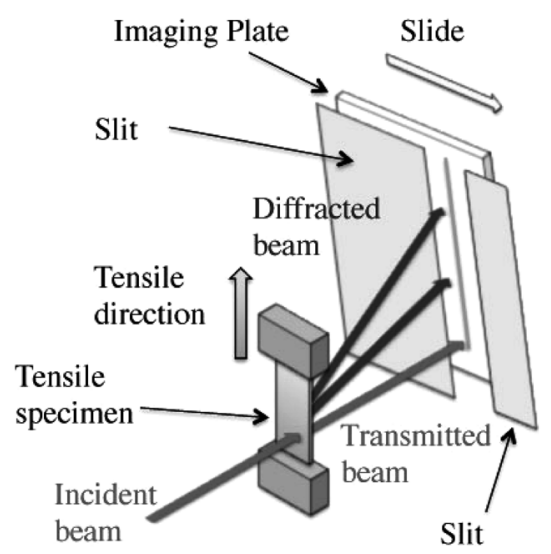

Fig. 2 A schematic illustration of the in-situ XRD measurement system.

結晶粒径とした。

引張変形を進めながらの転位密度の変化をIn-situ測定す るためには広い回折角度範囲にわたる回折プロファイル 変化を短時間で行う必要がある。よって, 本研究では高 輝度X線を用いることができる SPring-8 放射光施設の BL19B2ビームラインを用いた。Fig. 2 に測定系の模式図を示

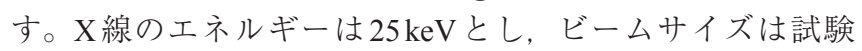
片幅方向に $3 \mathrm{~mm}$, 引張方向に $110 \mu \mathrm{m}$ とした。また, 広い 回折角度範囲を同時に, かつ, 角度分解能の高い測定を 行うため検出器として Imaging Plate（IP）を用いた。ただ し, IP は時間分解能を持たないことから, IPの前に幅 $4 \mathrm{~mm}$ のスリットを配置し, 引張試験開始とともにIPをスリット と垂直方向に $2 \mathrm{~mm} / \mathrm{s}$ で動かすことにより IP 上の各位置に各 時間に扮ける回折プロファイルを記録した。よって, 本実

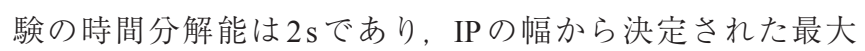
測定時間は $80 \mathrm{~s}$ であった。引張試験片に垂直にX線を入射 し, その透過配置にIPを水平方向から $14.7^{\circ}$ 上方に傾けて 配置した。試料とIPの距離は $716.6 \mathrm{~mm}$ である。これによ り, (111), (200), (220), (311), (222) 面の回折ピークを 同時に測定できた。得られた回折ピークプロファイルを擬 Voigt関数によりフィッティングし, 半值幅を求めた。引張 試験は初期ひずみ速度 $8.3 \times 10^{-4} \mathrm{~s}^{-1}$ で室温にて行った。なお， いずれの試料においてもネッキングや破断が生じた箇所には X線は照射されておらず，測定された結果は破断部近傍のも 

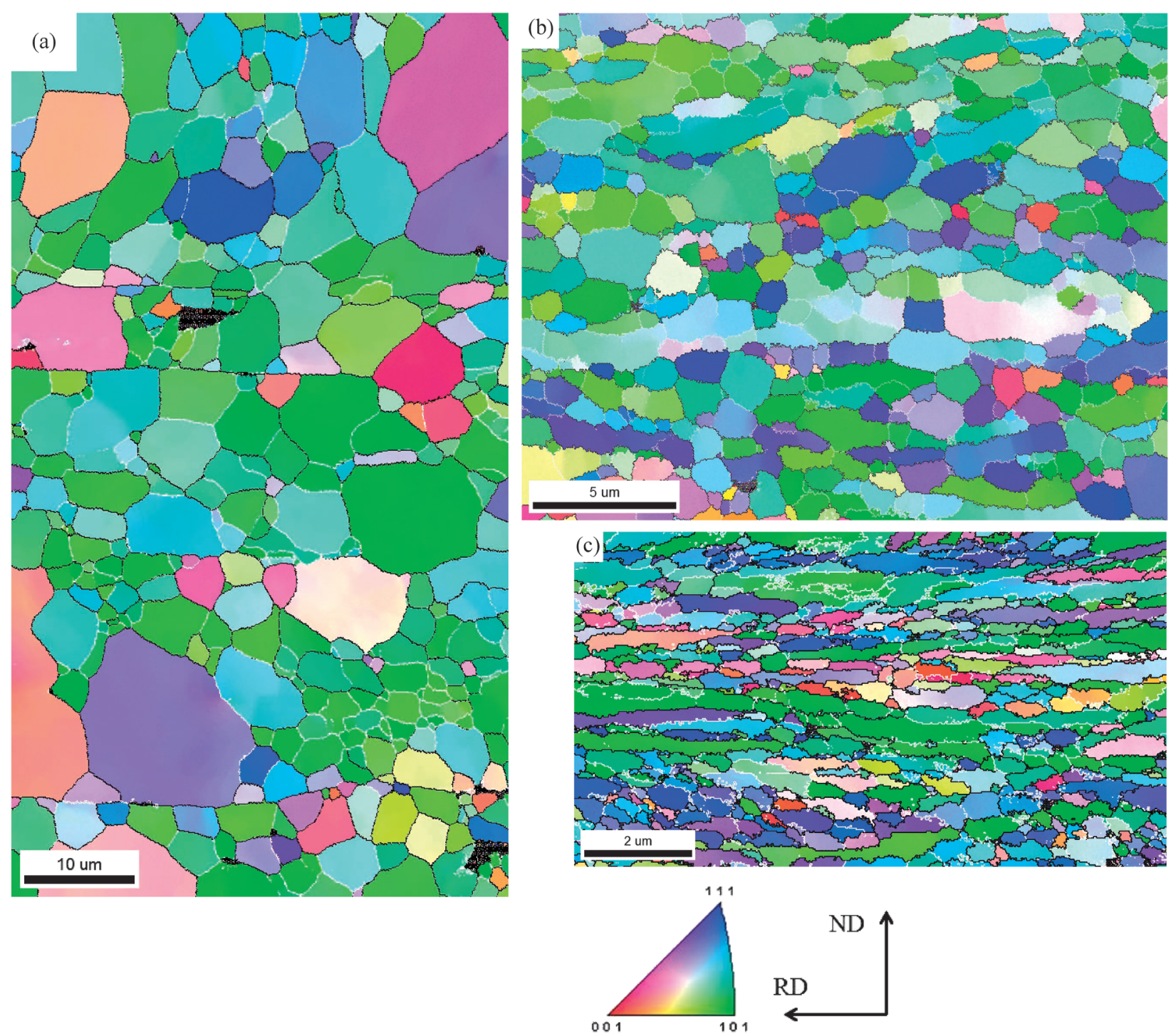

Fig. 3 TD inverse pole figure maps of ND-RD planes, (a) in the coarse grained (CG) aluminum, (b) in the fine grained (FG) aluminum and (c) in the ultra-fine grained (UFG) aluminum. Black lines correspond to the boundaries of misorientation angle $>15$ degree. White lines correspond to the boundary of misorientation angle $<15$ degree.

のではない。

\section{3. 結果}

Fig. 3 に各種焼なましにより粒径を調整した試料の ND-RD 断面の粒界マップを示す。(a) $448 \mathrm{~K}, 21.6 \mathrm{ks}+573 \mathrm{~K}, 1.8 \mathrm{ks}$ 焼なましを行った試料では結晶粒の形状は等軸に近かっ た。ND方向に扔ける大角粒界の平均間隔を測定した結果, $4.47 \mu \mathrm{m}$ であり, 以後, この試料を粗大粒 $(\mathrm{CG})$ 材と呼 ぶ。（b） $448 \mathrm{~K}, 21.6 \mathrm{ks}+498 \mathrm{~K}, 1.8 \mathrm{ks}$ 焼なましを行った試料で は, UFG 材と比較して結晶粒の形状がやや等軸に近く, 結 晶粒成長が進行していた。ND方向に打ける大角粒界の平均 間隔を測定した結果， $960 \mathrm{~nm}$ であり，以後，この試料を微細 粒（FG）材と呼ぶ。(c) $373 \mathrm{~K}$ 焼なまし材では, $\mathrm{RD}$ 方向に 伸長した粒が多く見られ，粒内に小角粒界はあまり見られな かった。ND方向に扔ける大角粒界の平均間隔を測定した結 果, $260 \mathrm{~nm}$ であった。この值を粒径と見なし, 以後, この試 料を超微細粒（UFG）材と呼ぶ。

次に, Fig. 4 にIn-situ XRD測定時に得られた応力ひずみ 曲線を示す。なお, 引張試駼機のストローク変化からひず
み量を計算しているため, ひずみ量には引張試験機の変形 量が含まれている。UFG材では連続降伏を示した。 $0.2 \%$ 耐 力 $\left(\sigma_{0.2}\right)$ はひずみ量 $\varepsilon_{0.2}=1.22 \%$ において $302 \mathrm{MPa}$ であった。 その後, ひずみ量 $3 \%$ まで加工硬化し, 引張強度 $373 \mathrm{MPa}$ 示した後, 徐々に局部変形に伴う応力低下を示し, ひずみ 量 $4.9 \%$ で破断した。FG材では $0.2 \%$ 耐力は $\varepsilon_{0.2}=0.98 \%$ におい て $\sigma_{0.2}=205 \mathrm{MPa}$ であった。その直後, 最大強度 $207 \mathrm{MPa}$ を示 した後，10Pa程度の急激な応力低下を示し，ひずみ量 $1.16 \%$ では193 MPaであった。通常, fcc金属であるアルミニウム は連続降伏を示すが, 結晶粒を微細化すると不連続降伏を示 すことが報告されている ${ }^{8)}$ 。その後, 徐々に局部変形に伴う 応力低下を示し, ひずみ量 $2.3 \%$ で破断した。UFG材と比べ て燒なましが進行し, 粒径が粗大になっているにもかかわら ず，延性が低下した。CG材では連続降伏を示した。しかし ながら，ひずみ量0 0.8\%の直線領域の傾きが $\mathrm{UFG}$ 材や FG 材と比べて小さかった。この直線領域を弾性変形域と見なし たときの $0.2 \%$ 耐力は $\sigma_{0.2}=78 \mathrm{MPa}$ であった。仮に, UFG材や $\mathrm{FG}$ 材の弾性域と同じ傾きを用いて $0.2 \%$ 耐力を求めた場合, $\varepsilon_{0.2}=0.31 \%$ において $\sigma_{0.2}=28 \mathrm{MPa}$ であった。ひずみ量 $0.8 \%$ を 


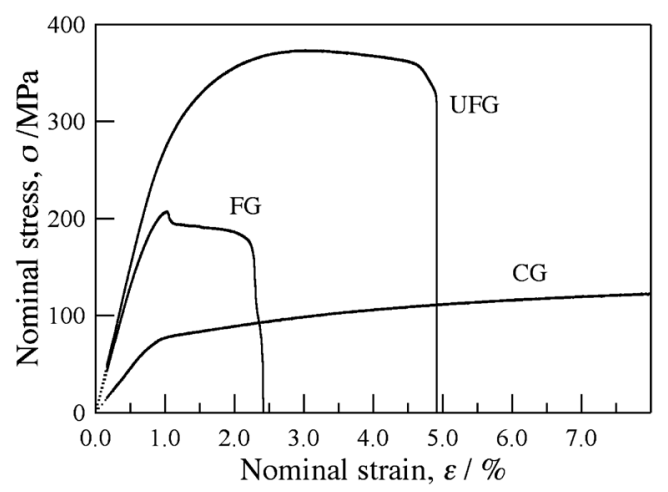

Fig. 4 Nominal stress-strain curves for the CG, FG and UFG aluminum during in-situ XRD measurements.

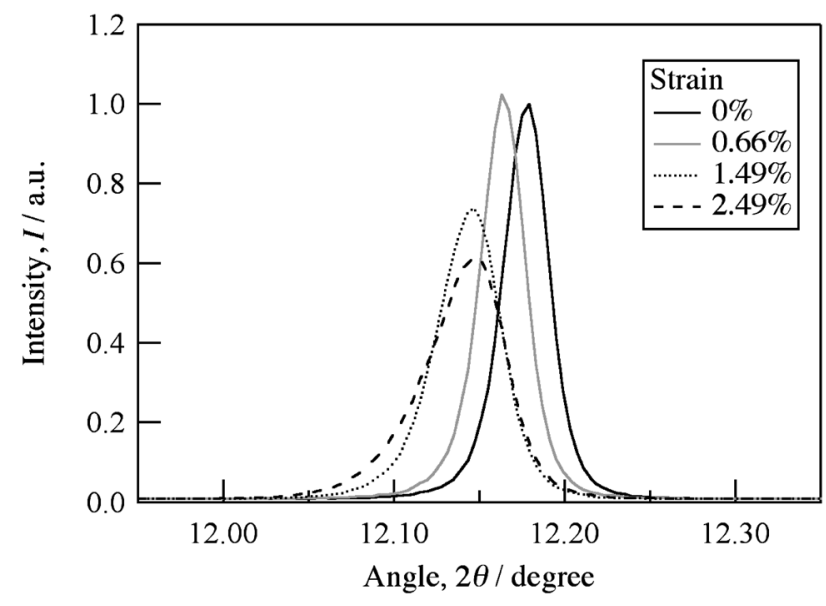

Fig. 5 (111) diffracted peaks at various nominal strains for the UFG aluminum during in-situ XRD measurements.

過ぎるとひずみ量の増加に伴う強度の増加は緩やかになっ た。また，塑性伸びが大きかったため，In-situ XRD測定中 に破断しなかった。

Fig. 5 にUFG 材の（111）回折ピークのひずみ量変化を示す。 ひずみ無負荷状態とひずみ量 $0.66 \%$ では回折ピーク形状はほ とんど変わらなかったが，回折ピーク角度が低角側に移行し た。ピーク角度の低角度側への移行は（111）面間隔の増加 を意味し，弾性変形によって（111）面間隔が引張方向に増 加したためである。

その後, ひずみ量 $1.49 \%$ では弾性変形によりひずみ量 $0.66 \%$ よりもピーク位置がさらに低角側に移行し, 回折ピー ク幅が増加した。ひずみ量 $2.49 \%$ に増加すると, 回折ピーク 角度はほとんど変化しなかったが，さらに回折ピーク幅が増 加した。回折ピーク幅の増加は不均質ひずみの増加もしく は, 結晶子サイズの減少により生じるため, 塑性変形の進行 によってこれらの一方，もしくはいずれもが増加したと考え られる。回折ピーク幅に対する不均質ひずみによる影響と結 晶子サイズによる影響の分離をWilliamson-Hallの式を用い て行った ${ }^{15)}$ 。

$$
\frac{\Delta 2 \theta \cos \theta}{\lambda}=\frac{0.9}{D}+2 \varepsilon \frac{\sin \theta}{\lambda}
$$

ここで $\Delta 2 \theta$ は回折ピークの半值幅, $\theta$ は回折角度, $\lambda$ は入射 $\mathrm{X}$ 線の波長, $\varepsilon$ は不均質ひずみ, $D$ は結晶子サイズである。 各回折ピークの $\Delta 2 \theta$ と $\theta$ を測定し, 横軸に $2 \sin \theta / \lambda$, 縦軸に

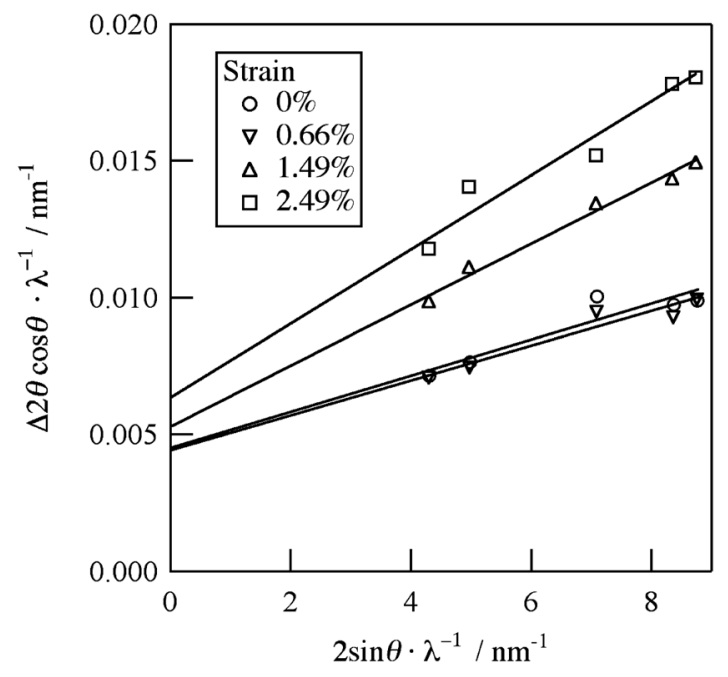

Fig. 6 Williamson-Hall plots at various nominal strains for the UFG aluminum.

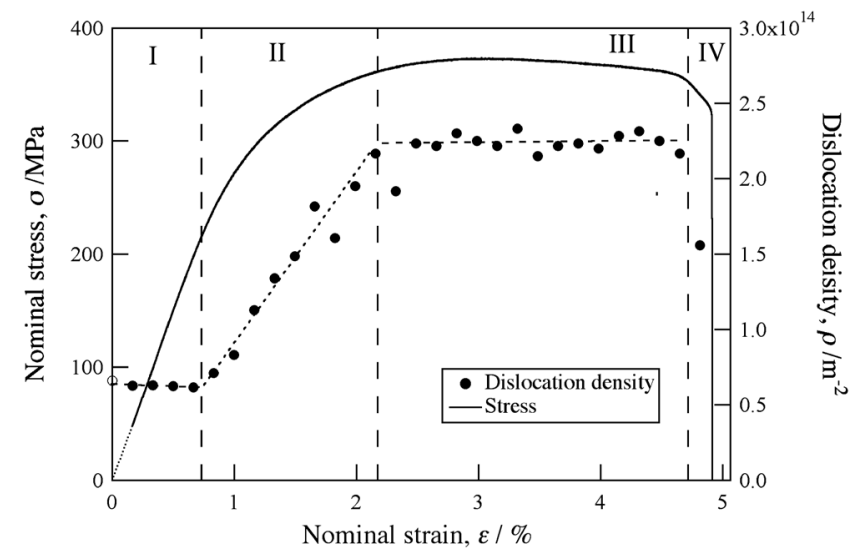

Fig. 7 Change in the dislocation density with the nominal strain for the UFG aluminum during the in-situ XRD measurement. Greek letter indicates each region. Vertical broken line is the region boundary.

$\Delta 2 \theta \cos \theta / \lambda$ を取ることにより，傾きから不均質ひずみ，縦軸 切片の逆数から結晶子サイズを求めることができる。Fig. 6 に超微細粒材に抢ける Williamson-Hall プロットを示す。い ずれの点も抢扮む权直線上に載って扮り, Williamson-Hall の式によく従うことがわかる。ひずみ無負荷状態とひずみ 量 $0.66 \%$ では, Williamson-Hall プロットの傾きおよび切片の 值にほとんど変化がなく，不均質ひずみ，結晶子サイズにほ とんど変化がないことがわかった。また，さらにひずみ量が 1.49\%, 2.49\%と増加することにより, Williamson-Hall プロッ トの傾きが徐々に増加し，不均質ひずみが増加した。また， 切片の值もわずかに増加したことから，ひずみ量の増加によ り結晶子サイズもわずかに低下したことがわかった。

Williamson-Hall プロットから求めた不均質ひずみ, 結晶子 サイズから以下の式を用いることで転位密度 $\rho$ を求めること ができる ${ }^{17)}$

$$
\rho=\frac{2 \sqrt{3} \varepsilon}{D b}
$$

Fig. 7 に In-situ XRD測定により求めた UFG 材における引 張変形中の転位密度変化を示す。UFG材に打ける転位密度 
の変化は図中に示す領域Iから IVの四段階に分けられる。ひ ずみ量 $0 \sim 0.75 \%$ までの領域 Iでは引張変形開始後, 転位密度 がほとんど変化しなかった。Fig. 5 に示すようにひずみ量 $0 \%$ と $0.66 \%$ における回折ピーク形状の変化はほとんどなく，回 折角度のみが低角側に移行していることから，この領域では 弾性変形のみが生じたと考えられる。領域Iから領域IIに移 行すると，転位密度が急激に増加したころから，塑性変形 が開始されたと考えられ，応力ひずみ曲線の傾きが領域Iよ り小さくなったこともこれを示唆している。領域Iから II に 移行する応力を $\sigma_{\mathrm{I}}$, ひずみ量を $\varepsilon_{\mathrm{I}}$, 転位密度を $\rho_{\mathrm{I}}$ すると, お おむね $\sigma_{\mathrm{I}}=220 \mathrm{MPa}, \varepsilon_{\mathrm{I}}=0.75 \%, \rho_{\mathrm{I}}=0.61 \cdot 10^{14} \mathrm{~m}^{-2}$ であった。 $\sigma_{\mathrm{I}}$ は $\sigma_{0.2}$ よりも $82 \mathrm{MPa}$ 低く, 転位の増殖は $0.2 \%$ 耐力よりもか なり低い応力から開始され， $0.2 \%$ 耐力を示すひずみ量では $\rho_{0.2}=1.20 \cdot 10^{14} \mathrm{~m}^{-2}$ まで転位密度は増加していた。その後, ひ ずみ量 $2.16 \%$ 付近まで転位密度は単調に増加した。領域 III では転位密度がほぼ一定となり, 領域IIから領域IIIに移行 する応力を $\sigma_{\mathrm{II}}$, ひずみ量を $\varepsilon_{\mathrm{II}}$, 転位密度を $\rho_{\mathrm{II}}$ すると, おお むね $\sigma_{\mathrm{II}}=361 \mathrm{MPa}, \varepsilon_{\mathrm{II}}=2.16 \%, \rho_{\mathrm{II}}=2.2 \cdot 10^{14} \mathrm{~m}^{-2}$ であった。ひず み量が $4.65 \%$ を過ぎた領域IVにおいて転位密度が急激に低 下した。これは試験片が破断しはじめたひずみ量と一致する ため, 破断に伴う応力低下により, 転位密度が低下したと考 えられる。転位密度の減少量は $0.6 \cdot 10^{14} \mathrm{~m}^{-2}$ であった。

Fig. 8 にIn-situ XRD 測定により求めたFG材における 引張変形中の転位密度変化を示す。FG材においても UFG 材 と同様，転位密度は領域 I〜IVの四段階で変化した。引張 試験開始後, 転位密度がほとんど変化しない領域Iが観察さ れる。ひずみ量 $\varepsilon_{I}=0.60 \%$ を超えて領域IIに入ると転位密度 が増加しはじめ, 応力ひずみ曲線の傾きが領域Iより小さく なった。このひずみ量 $\varepsilon_{I}=0.60 \%$ における応力と転位密度は それぞれ $\sigma_{\mathrm{I}}=153 \mathrm{MPa}, \rho_{\mathrm{I}}=0.28 \cdot 10^{14} \mathrm{~m}^{-2}$ であった。 $\sigma_{\mathrm{I}}$ はUFG材 のときと同様, $0.2 \%$ 耐力 $\sigma_{0.2}=205 \mathrm{MPa}$ よりも低く, FG 材に おいても $0.2 \%$ 耐力よりも低い応力から転位の増殖が開始さ れることがわかった。また， $0.2 \%$ 耐力時の転位密度は $\rho_{0.2}=$ $0.6 \cdot 10^{14} \mathrm{~m}^{-2}$ 程度であった。その後，ひずみ量 $1.16 \%$ 付近に かけて転位密度は増加を示した。領域IIにおいて応力ひず み曲線では $10 \mathrm{MPa}$ 程度の応力低下現象が観察されたが, 今 回のIn-situ測定における時間分解能や測定精度ではこの原因 については明らかにすることができなかった。しかしなが ら, 応力低下が生じる応力よりも $\sigma_{\mathrm{I}}$ は低いことから, 応力低 下現象が生じるひずみ量において可動転位が増加し，転位 が増殖しはじめたのではないことが明らかになった。領域 II と III の境界は明確ではないが， $\varepsilon_{\mathrm{II}}=1.16 \%$ を境界とすると， $\sigma_{\mathrm{II}}=194 \mathrm{MPa}, \rho_{\mathrm{II}}=0.79 \cdot 10^{14} \mathrm{~m}^{-2}$ であった。領域 III では転位密 度はほとんど変化せず，領域IVである試験片が破断するひ ずみ量 $2.3 \%$ 付近において転位密度が大幅に低下した。転位 密度の減少量は $0.3 \cdot 10^{14} \mathrm{~m}^{-2}$ 程度であり, UFG 材における減 少量の半分程度であった。つまり, 変形中に増殖した転位の 一部は除荷時に消滅し, 結晶粒径が小さい方がその消滅量は 多い。この結果は, 結晶粒径が微細な純アルミニウムでは, 荷重除荷後に透過電子顕微鏡を用いて転位密度を測定する方 法ではもちろんのこと，引張試験中にクロスヘッド移動を途 中で停止させている間に回折プロファイルを測定する方法に よっても, 応力緩和によって転位密度が減少するため, 変形 中の転位密度を過小評価することを意味している。また，転

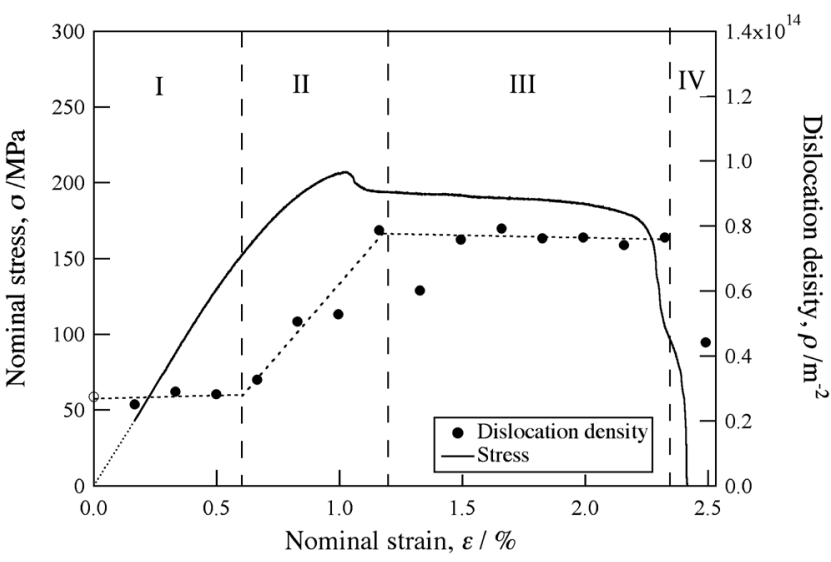

Fig. 8 Change in the dislocation density with the nominal strain for the FG aluminum during the in-situ XRD measurement. Greek letter indicates each region. Vertical broken line is the region boundary.

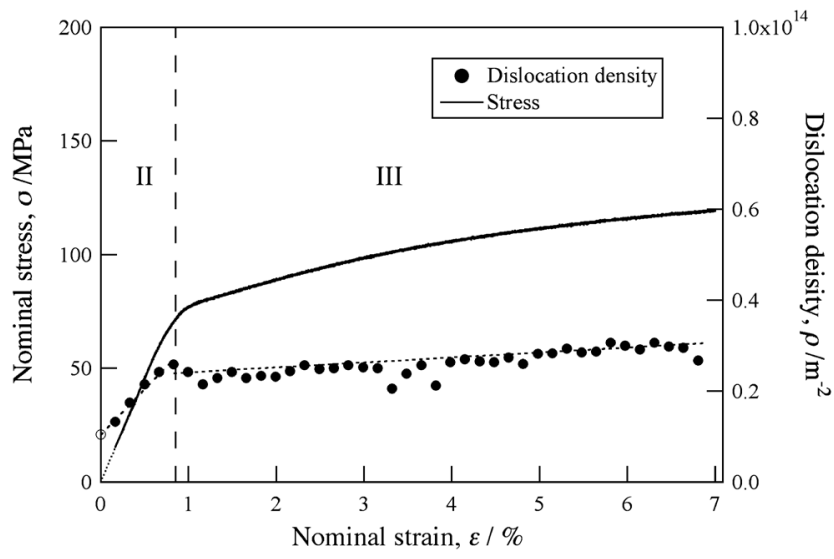

Fig. 9 Change in the dislocation density with the nominal strain for the CG aluminum during the in-situ XRD measurement. Greek letter indicates each stage. Vertical broken line is the stage boundary.

位組織そのものが除荷後では変形中とは変化している可能性 も考えられる。また, UFG材やFG材では結晶粒界密度が高 いため, 除荷に伴う変形によって, 転位が粒界に移動し, 粒 界をシンクとして消滅したことが可能性として考えられる が, どのようにして転位が消滅しているのかについては本実 験では明らかでない。

Fig. 9 にIn-situ XRD 測定により求めたCG材における引 張変形中の転位密度変化を示す。CG材では, 引張試験開 始後, 次の測定点であるひずみ量 $0.166 \%$ ではすでに転位密 度が増加しており, 明確な領域Iが観察されなかった。ひ ずみ量 $0.166 \%$ に拈りる応力は $14 \mathrm{MPa}$ であることから, CG 材では転位が増殖しはじめる応力 $\sigma_{\mathrm{I}}$ は $14 \mathrm{MPa} よ り$ 低い。ま た, 領域IIにおける転位密度はひずみ量に対してほぼ直線 的に変化しており，ひずみ量 $0 \%$ における転位密度がその直 線上に載ることから, 転位が増殖しはじめる応力 $\sigma_{\mathrm{I}}$ はかな り小さく, $0 \mathrm{MPa}$ にかなり近いと考えられる。よって, ここ では $\sigma_{\mathrm{I}}=0 \mathrm{MPa}, \varepsilon_{\mathrm{I}}=0 \%, \rho_{\mathrm{I}}=0.10 \cdot 10^{14} \mathrm{~m}^{-2}$ とする。その後, ひ ずみ量 $0.83 \%$ まで転位密度が大きく増加した。この結果か ら，ひずみ量 $0.83 \%$ 以下の領域は応力とひずみは直線関係 にはあるが, 領域 Iに対応する弾性変形領域ではなく, 領 


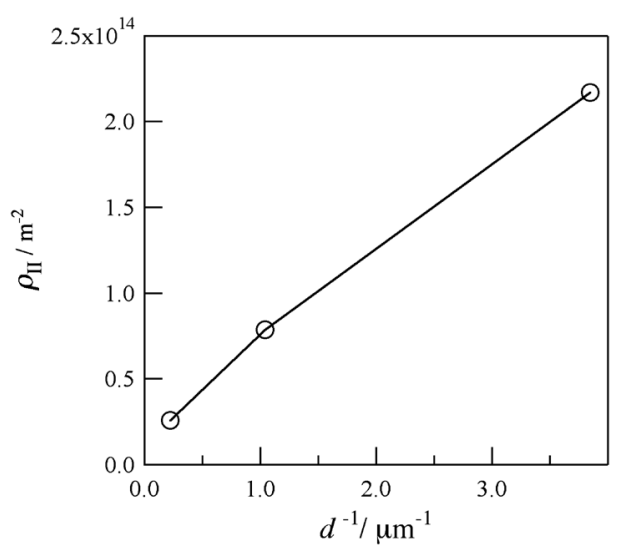

Fig. 10 Change in dislocation density, $\rho_{\text {II }}$ with the grain size. $\rho_{\text {II }}$ is the dislocation density at the transition point from the stage II to III.

域IIに対応する塑性変形領域であるため, CG 材における応 力ひずみ曲線の領域IIにおける傾きが, UFG材やFG材の弾 性変形領域の傾きよりも小さかったと考えられる。よって, CG材における $0.2 \%$ 耐力は UFG材や FG 材の領域 Iにおける 応力ひずみ曲線の傾きから $\sigma_{0.2}=28 \mathrm{MPa}$ であり， $\varepsilon_{0.2}=0.31 \%$, $\rho_{0.2}=0.18 \cdot 10^{14} \mathrm{~m}^{-2}$ である。ひずみ量が $0.83 \%$ よりも大きくな ると, 転位密度の増加速度が領域IIよりも緩やかになったこ とから, この領域は領域IIIに対応すると考えられる。よっ て，領域II とIIIの境界として， $\varepsilon_{\mathrm{II}}=0.83 \%$ とし，そのときの 応力と転位密度は $\sigma_{\mathrm{II}}=70 \mathrm{MPa}, \rho_{\mathrm{II}}=0.26 \cdot 10^{14} \mathrm{~m}^{-2}$ であった。

\section{4. 考察}

In-situ XRD 測定により, 引張变形の進行に伴う転位密度 の変化には以下の四段階があることが明らかになった。領域 Iは弾性変形領域であり, 転位密度がほとんど变化しない領 域である。領域II は転位が急激に増殖している領域である。 領域 III は転位の増殖が緩やかな領域であり, 領域 IV は破断 に伴う除荷により転位密度が急激に減少する領域である。

各領域の移行が何によって決定されるのか, まず領域IIか ら領域IIIへの移行を考える。領域II は急激に転位が増殖し ている段階であり, 転位密度が $\rho_{\text {II }}$ に達すると, 領域 III に移 行する。 $\rho_{\text {II }}$ と結晶粒径の関係を Fig. 10 に示す。 $\rho_{\text {II }}$ は結晶粒 径の逆数におおむね比例していることがわかる。領域 II, III は塑性変形が進行している領域であるが, 塑性変形における せん断変形速度 $\mathrm{d} \gamma / \mathrm{d} t$ は以下の式で表される ${ }^{20)}$ 。

$$
\frac{\mathrm{d} \gamma}{\mathrm{d} t}=\rho v b
$$

ここで, $v$ は転位の平均運動速度, $\rho$ は転位密度, $b$ はバーガー スベクトルである。今回の測定では，一定速度の引張試験を 行っているため $\mathrm{d} \gamma / \mathrm{d} t$ は一定である。塑性変形初期は転位密 度が小さいため, 弾性変形から塑性変形に移行した後も一定 のせん断変形速度を持続させるためには, 転位密度が増加す るか，もしくは転位の運動速度が増加する必要がある。粒界 は転位移動の障害となるため, 転位が容易に運動できる長さ はせいぜい結晶粒径程度であるとすると, 結晶粒径の減少

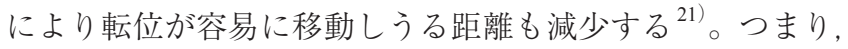
転位が障害なく運動する際の運動速度よりも，結晶粒が微細 になると，粒内を移動している時間が短くなり，粒界近傍で

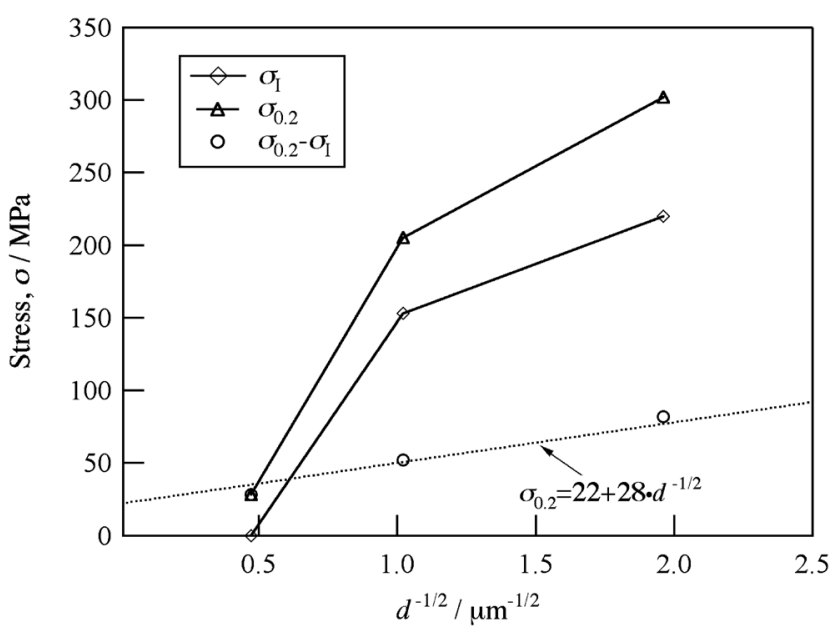

Fig. 11 Change in the $0.2 \%$ proof stress, $\sigma_{0.2}$, the stress $\sigma_{\mathrm{I}}$ and the difference between $\sigma_{0.2}$ and $\sigma_{\mathrm{I}}$ with the grain size. $\sigma_{\text {I }}$ is the stress at the transition point from the stage I to II. The dash line indicates the Hall-Petch relationship for coarse grained pure aluminums reported by Kamikawa ${ }^{8)}$.

停止する時間が長くなるため, 転位の平均運動速度が減少す ると考えられる。よって, UFG材やFG材においては, 一定 速度で変形を持続させるためには粗大粒材よりも転位密度が 増加する必要がある。ここで粗い仮定として, 転位が粒内を 十分に速い速度で運動し, 粒界近傍で停止すると考えると, 転位の平均運動速度 $v$ は障害である結晶粒界の密度によって 決定され, 結晶粒径に比例する。その結果, 一定速度の塑性 変形が生じるために必要な転位密度は結晶粒径に反比例す る。つまり, 領域IIにおける転位密度の急激な増加は, 一定 速度の塑性変形に必要な転位密度 $\rho_{\text {II }}$ まで増加するために生 じたと考えられる。そのため，特にUFG材ではFG材やCG 材よりも領域IIにおいて転位密度が急激に増加する必要があ り, 応力ひずみ曲線の傾きが弾性変形領域における傾きから あまり低下せず，実際に転位が増殖しはじめる応力 $\sigma_{\mathrm{I}}$ よりも $0.2 \%$ 耐力 $\sigma_{0.2}$ がかなり大きくなったと考えられる。

次に粒径の- $1 / 2$ 乗に対する $\sigma_{\mathrm{I}}, \sigma_{0.2}$ および $\sigma_{\mathrm{I}}$ と $\sigma_{0.2}$ の差の 変化を Fig. 11 に示す。なお，点線は粗大粒を有した $99 \%$ 純アルミニウムにおいて報告されたHall-Petch 関係 $\left(\sigma_{0.2}=\right.$ $\left.9.7+41 d^{-1 / 2}\right)$ である ${ }^{22)}$ 。粒径 $4.47 \mu \mathrm{m}$ の $\mathrm{CG}$ 材では $\sigma_{0.2}$ が粗 大粒 Hall-Petch 関係に載ったが, FG 材と UFG 材では粗大粒 Hall-Petch 関係の延長線上よりも $\sigma_{0.2}$ はかなり大きい応力を 示した。ただし, In-situ XRD測定が明らかにしたように， $\sigma_{0.2}$ を示すのは, 前述のように一定速度の塑性変形に必要な転位 密度 $\rho_{\text {II }}$ まで増加する領域II の途中においてであるため, 特 にUFG材やFG材では転位密度がすでに大きく上昇してお $\eta, \sigma_{0.2}$ は降伏応力, つまり塑性変形開始応力を評価する值 としては適当ではない。では, 転位が増殖しはじめる応力 $\sigma_{\mathrm{I}}$ を塑性変形開始応力として採用すると, FG 材と UFG 材で は $\sigma_{\mathrm{I}}$ も粗大粒 Hall-Petch 関係の延長線上よりもかなり大きな 応力を示す。一方, $\mathrm{CG}$ 材ではほぼ $\sigma_{\mathrm{I}}=0 \mathrm{MPa}$ であり， $\sigma_{\mathrm{I}}$ は粗 大粒 Hall-Petch 関係よりも小さくなった。今回の研究では調 べていないが, 粒径が粗大である方が降伏しやすいため, 粒 径が $5 \mu \mathrm{m}$ 以上であっても $\sigma_{\mathrm{I}}$ はほぼ $0 \mathrm{MPa}$ に近いであろうと予 想される。これらのことから, 純アルミニウムでは, 粒径が 
$5 \mu \mathrm{m}$ 程度までは転位の増殖はわずかに応力を負荷しただけ でも生じるが，それ以上微細になると転位の増殖が急激に困 難になると考えられる。粒内の Frank-Read源から転位が増 殖するとき，転位源の活性化に必要な応力 $\sigma$ は次式により表 される ${ }^{23)}$ 。

$$
\sigma=\frac{M \mu b}{L}
$$

$M$ はテイラー定数, $\mu$ は剛性率, $b$ はバーガースベクトル長 さ，Lは転位源長さである。この式にアルミニウムの值とし て $\sigma=\sigma_{\mathrm{I}}, M=3.06, \mu=26 \mathrm{GPa}, b=0.286 \mathrm{~nm}$ を代入すると, UFG 材, $\mathrm{FG}$ 材では転位源長さはそれぞれ $L=103 \mathrm{~nm}, 149 \mathrm{~nm}$ と求 められる。Frank-Read源として粒内の林立転位を考えると， 粗い近似として，林立転位が間隔 $L て ゙$ 格子状に並んでいると 仮定すると, 転位密度は $\rho=L^{-1 / 2}$ となる。このとき, UFG 材, $\mathrm{FG}$ 材ではそれぞれ $\rho=0.93 \cdot 10^{14} \mathrm{~m}^{-2}, 0.45 \cdot 10^{14} \mathrm{~m}^{-2}$ と求められる。 In-situ XRD 測定で求めた值はUFG 材では $\rho_{\mathrm{I}}=0.61 \cdot 10^{14} \mathrm{~m}^{-2}, \mathrm{FG}$ 材では $\rho_{\mathrm{I}}=0.28 \cdot 10^{14} \mathrm{~m}^{-2}$ であり, 同程度の值が得られた。こ のことから, 微細粒材では粒径が小さいため, 活動可能な転 位源長さが短くなり，転位増殖に必要な応力が大きくなった のではないかと予想される。

それでは従来報告されていた粗大粒アルミニウムの HallPetch 関係とは何を示すのか。 $\sigma_{0.2}$ は $0.2 \%$ 塑性変形が生じた ときに示す応力ではあるが，粗大粒材では転位が増殖しはじ める応力 $\sigma_{\mathrm{I}}$ がほぼ $0 \mathrm{MPa}$ に近いため, $\sigma_{0.2}=\sigma_{0.2}-\sigma_{\mathrm{I}}$ でもある。 $\mathrm{FG}$ 材とUFG材においても $\sigma_{\mathrm{I}}$ と $\sigma_{0.2}$ の差をとり, Fig. 11 中に 示すと，おおむね粗大粒アルミニウムの Hall-Petch 関係の延 長線上に載ることがわかる。よって，従来の粗大粒純アルミ ニウムの Hall-Petch 関係とは， $0.2 \%$ 耐力 $\sigma_{0.2}$ ではなく， $0.2 \%$ 耐力と転位が増殖しはじめる応力， $\sigma_{0.2}-\sigma_{\mathrm{I}}$ の粒径依存性を 調べたものであると言うことができる。

\section{5. 結言}

放射光を用いたIn-situ XRD 測定によって，結晶粒径がそ れぞれ $260 \mathrm{~nm}, 960 \mathrm{~nm}, 4.47 \mu \mathrm{m}$ の UFG 材, FG 材, CG 材にお ける引張変形中の転位密度変化を調べた結果, 以下のことが わかった。

（1）ひずみ量の増加に伴い, 転位密度は四段階を経て変 化することがわかった。第一段階は, 弾性変形領域であり, 転位密度がほとんど変化しない領域である。第二段階は転位 密度が急激に増加する領域，第三段階は転位密度が緩やかに 変化する領域である。

（2）第四段階は試験片破断に伴い，転位密度が急激に減 少する領域であり，UFG材やFG材では転位密度が大きく低 下した。その減少量は結晶粒径が微細であるほど大きかっ た。このことから，UFG材における変形中の転位密度を測 定するためにはIn-situ測定が必要であり，微細粒材では変形 中の転位組織が除荷後の転位組織とは大きく異なることが予 想される。

（3）転位が増殖しはじめる応力 $\sigma_{\mathrm{I}}$ は $\mathrm{CG}$ 材では $0 \mathrm{MPa}$ に近

く，第一段階の弾性変形領域がほとんど観察されなかった。 $\sigma_{\mathrm{I}}$ は結晶粒径の減少により増加し，FG材では $153 \mathrm{MPa}, \mathrm{UFG}$
材では $220 \mathrm{MPa}$ まで増加した。その結果，粗大粒アルミニウ ムにおける Hall-Petch関係の延長により求められる応力より も非常に高くなった。

(4) 第二段階から第三段階に移行するときの転位密度 $\rho_{\text {II }}$ は結晶粒径に反比例し，結晶粒が微細なほど $\rho_{\text {II }}$ は増加した。 このことから，第二段階は一定速度の塑性変形に必要な転位 密度 $\rho_{\text {II }}$ で増加することによって生じたと考えられる。

（5）転位が増殖しはじめる応力 $\sigma_{\mathrm{I}}$ と $0.2 \%$ 耐力 $\sigma_{0.2}$ の差は, 粗大粒アルミニウムにおける Hall-Petch 関係の延長上に載っ たことから，従来報告されていたHall-Petch 曲線は $\sigma_{0.2}-\sigma_{\mathrm{I}}$ の 粒径依存性であると考えられる。

謝 辞

本研究は (公財) 軽金属奨学会, 文部科学省科学研究費補 助金・新学術領域研究「バルクナノメタル〜常識を覆す新し い構造材料の科学」による支援を受けて行われました。また， 本研究の放射光実験は (公財) 高輝度光科学研究センター SPring-8 の BL19B2（課題番号：2011B1923, 2012A1123）に て行われました。ここに謝意を表する。

\section{参 考 文 献}

1) N. Tsuji, Y. Ito, Y. Saito and Y. Minamino: Scr. Mater., 47 (2002), 893-899.

2) Y. Saito, N. Tsuji, H. Utsunomiya, T. Sakai and R. G. Hong: Scr. Mater., 39 (1998), 1221-1227.

3) X. Huang, N. Tsuji, N. Hansen and Y. Minamino: Mater. Sci. Eng. A, 340 (2003), 265-271.

4) Z. Horita and T. G. Langdon: Mater. Sci. Eng. A, 410-411 (2005), 422-425.

5) S. Ferrasse, K. T. Hartwig, R. E. Goforth and V. M. Segal: Metall. Mat. Trans. A, 28 (1997), 1047-1057.

6) E. Q. Hall: Proc. Phys. Soc. Lond., B64 (1951), 747-751.

7) N. J. Petch: J. Iron Steel Inst., 174 (1953), 25-28.

8) N. Kamikawa, X. Huang, N. Tsuji and N. Hansen: Acta Mater., 57 (2009), 4198-4208.

9) 紙川尚也, 辻 伸泰, 齋藤好弘：鉄と鋼, 89（2003），273-280.

10) X. Huang, N. Hansen and N. Tsuji: Science, 312 (2006), 249-251.

11) X. Huang, N. Kamikawa and N. Hansen: Mater. Sci. Eng. A, 483-484 (2008), 102-104.

12）小松伸也：塑性と加工，46（2005），813-817.

13) Y. Miyajima, M. Mitsuhara, S. Hata, H. Nakashima and N. Tsuji: Mater. Sci. Eng. A, 528 (2010), 776-779.

14) S. Hata, H. Miyazaki, S. Miyazaki, M. Mitsuhara, M. Tanaka, K. Kaneko, K. Higashida, K. Ikeda, H. Nakashima, S. Matsumura, J. S. Bamard, J. H. Sharp and P. A. Midgley: Ultramicroscopy, 111 (2011), $1168-1175$.

15) G. K. Williamson and W. H. Hall: Acta Metall., 1 (1953), 22-31.

16) G. K. Williamson and R. E. Smallman: Philos. Mag., 8 (1956), 34- 45.

17) G. K. Williamson and R. E. Smallman: Acta Crystallogr., 7 (1954), 574-581.

18) Y. Tomota, P. Lukas, S. Harjo, J.-H. Park, N. Tuchida and D. Neov: Acta Mater., 51 (2003), 819-830.

19）諸岡 聡, 友田 陽, 足立吉隆, 森戸茂一, 神山 崇 : 鉄と鋼, 94 (2008), 313-320.

20) W. G. Jonston and J. J. Gilman: J. Appl. Phys., 30 (1959), 129-144

21) C. Y. Yu, P. W. Kao and C. P. Chang: Acta Mater., 53 (2005), 40194028.

22) N. Kamikawa: PhD Thesis, Osaka University, (2005).

23) D. Hull and D. J. Bacon: Introduction to Dislocations fifth ed. Butterworth Heinemann, (2011), 164. 